TARNOWSKIE STUDIA TEOLOGICZNE 35 (2016) NR 2, S. 125-140

http://dx.doi.org/10.15633/tst.2109

ks. Tomasz Stec ${ }^{1}$

UNIWERSYTET PAPIESKI JANA PAWŁA II W KRAKOWIE

\title{
Donacja organów a logika daru. Chrześcijańskie spojrzenie na problem transplantacji
}

Transplantologia jest dzisiaj bardzo ważną częścią medycyny. Dzięki jej zabiegom życie ludzkie można uratować i przedłużyć nawet o kilkadziesiąt lat. Operacje i zabiegi transplantologiczne są powszechnie stosowane już od ponad pięćdziesięciu lat. Na temat dawstwa pozytywnie wypowiadają się dzisiaj różne autorytety moralne. W donacji widzimy nadzieję na ratowanie zagrożonego życia. Osoby będące dawcami wskazuje się jako przykład godny do naśladowania. Jest to postawa altruistyczna, która wymaga w tym wypadku szczególnego rozumienia dawstwa jako logiki daru z siebie.

Każdy człowiek może zostać dawcą organów. Celem artykułu jest uwrażliwienie społeczeństwa na problem donacji. Większa liczba dawców to większa szansa dla chorych na normalne życie. Wzrasta dziś zapotrzebowanie szczególnie na świadomych dawców, którzy dobrowolnie opowiedzą się za ofiarowaniem swoich narządów zwłaszcza w momencie śmierci, poprzez zgłaszanie się do rejestru dawców lub bynajmniej noszenie przy sobie informacji potwierdzającej zgodę na pobranie organów w przypadku śmierci. Świadomym dawcą organów może być tylko taki człowiek, który rozumie, czym jest dar z siebie. Artykuł prezentuje donację jako akt altruistyczny i ma na celu do takiej postawy zachęcać.

Przywołana nauka Kościoła na ten temat mówi o wspólnej odpowiedzialności społecznej za każde życie. Określa, jak winna wyglądać moralna postawa chrześcijańska wobec donacji. Z drugiej strony Magisterium Kościoła

\footnotetext{
1 Tomasz Stec - kapłan archidiecezji przemyskiej, ukończył studia magisterskie w Przemyślu w 2010 roku, pracował jako wikariusz w parafii Dubiecko i Strachocina. Od 2014 roku podejmuje studia licencjacko-doktoranckie na Papieskim Uniwersytecie Jana Pawła II w Krakowie. W 2015 roku uzyskał tytuł magistra licencjata z teologii moralnej, specjalizacja bioetyka.
} 
sprzeciwia się powszechnemu stosowaniu w wielu krajach świata tzw. zgody domniemanej, a także przestrzega przed niedopuszczalnymi działaniami w transplantologii. Celem artykułu jest także prezentacja niektórych malwersacji pojawiających się przy przeszczepach. Spostrzeżenia te winne wyczulić na możliwe tutaj nieetyczne działania człowieka.

\section{Osiągnięcia i wyzwania współczesnej transplantologii}

Od momentu pierwszego przeszczepu nerki, której w 1954 roku dokonał Joseph E. Murray ${ }^{2}$ i od pierwszego przeszczepienia serca w dokonanego w 1967 roku przez zespół medyczny Christiana Barnarda ${ }^{3}$, wiele zmieniło się w transplantologii. Dzisiaj dokonujemy bez większych problemów i powikłań przeszczepu organów, takich jak serce, wątroba, nerka czy trzustka. Przeszczepiane są także tkanki i komórki. Nierzadkie są transplantacje płuc, jelit lub kończyny oraz komórek krwiotwórczych, fragmentów kostnych, czy nawet rogówki oka ${ }^{4}$.

Wraz z rozwojem medycyny spadł o ponad połowę problem powikłań, jakie na początku pojawiały się po przeszczepie. Powstają wciąż nowe leki immunosupresyjne, dzięki którym długość życia pacjentów po przeszczepie nieustannie wzrasta. Prowadzone obserwacje wykazały, że biorca nerki po przeszczepie może przeżyć nawet kolejne 4o lat. Pacjenci po przeszczepie wątroby najdłużej żyli 30 lat, po przeszczepie serca 23 lata, trzustki 18 lat, po przeszczepie płuc 13 lat $^{5}$.

Problemem jest jednak nadal brak wystarczającej liczby organów do transplantacji. Podwójne narządy zazwyczaj pozyskuje się od osób bliskich. Sytuacja staje się trudniejsza, gdy pojawia się zapotrzebowanie

2 Por. J. Skalski, Historia przeszczepiania narządów, „CX-News” 28 (2009) nr 2, s. 244; J. Sobiak, Przeszczepianie narządów i komórek krwiotwórczych - rys historyczny, „Nowiny Lekarskie” 80 (2011) nr 2, s. 157-161.

3 Por. R. Hoffenberg, Christiaan Barnard: his first transplants and their impact on concepts of death, „British Medical Journal” 12 (2001), s. 22-27.

4 Por. M. Lanzetta, P. Petruzzo, G. Vitale i in., Human hand transplantation: what have we learned?, „Transplantation Proceedings” 36 (2004), s. 664-668.

5 Por. J. Wałaszewski, D. Stryjecka-Rowińska, Dawcy narządów, rozpoznanie śmierci mózgowej, w: Transplantologia kliniczna, red. W. Rowiński, J. Wałaszewski, L. Pączek, Warszawa 2004, s. 35-49. 
na narządy pojedyncze. Najczęściej pobiera się je wówczas od dawców zmarłych ${ }^{6}$. Niestety przeszczepione w ten sposób organy bywają częściej odrzucane przez organizm biorcy. Wynika to między innymi z tego, że niedokrwienie organów nawet przez krótki okres wpływa na powodzenie przeszczepu? Problemem jest również wciąż rosnąca liczba oczekujących na transplantacje i ciągle niewystarczająca liczba dawców. $Z$ drugiej strony zadowalające jest to, że co rok wzrasta liczba dawców w krajowym rejestrze. Coraz więcej pojawia się osób pragnących zostać dawcą szpiku. Nerki i fragmenty wątroby najczęściej nadal oddawane są przez kogoś z rodziny chorego. Wciąż jednak trzeba promować świadomych dawców, którzy poprzez swoją postawę ratują życie innych ludzi.

Dzięki nagłaśnianiu problemu donacji rośnie liczba przeszczepów. W Polsce w 2009 roku na przeszczep nerki czekało 1768 osób, otrzymało ją 762 biorców. Dla porównania w 2007 roku na taki przeszczep oczekiwało 1621 osób, doczekało się jej 674 biorców; natomiast w 2006 roku przeszczepiono wszystkich nerek 917, a w 2005-1069. Wliczono tu również dawców żywych spośród najbliżej rodziny ${ }^{8}$.

Transplantacja (łac. transplantare - szczepić, przesadzić), czyli przeszczepienie z organizmu dawcy do organizmu biorcy narządów, komórek lub tkanek, wymaga odpowiednich unormowań prawnych i moralnych. Żadnej pożądanej części organizmu w przypadku chorego pacjenta nie można w żadnym wypadku kupować, przekazanie zaś musi nastąpić za wcześniejszą zgodą dawcy. Dyskusyjna i problematyczna jest stosowana dziś powszechnie zgoda domniemana, w myśl której można pobrać organy od osoby, która wcześniej nie wyraziła wobec tego sprzeciwu ${ }^{9}$ Dylematy pojawiające się przy transplantologii wymagały odpowiednich rozwiązań prawnych. Ustawy

6 Por. „Poltransplant. Biuletyn Informacyjny” z maja 2014 roku wydawany przez Centrum Organizacyjno-Koordynacyjne ds. Transplantacji „Poltransplant” podaje, że zdecydowana większość narządów pozyskiwana jest właśnie w ten sposób. W 2014 roku przeszczepiono 1531 organów, podczas gdy w roku 2013 od zmarłych dawców pochodziło ich 1536, a w roku 2012 1545 .

7 Por. „Poltransplant. Biuletyn Informacyjny”, s. 16.

8 Por. B. Dąbrowska, Próby komercjalizacji idei transplantacyjnej w świetle rozstrzygnięć w prawie międzynarodowym, „Medycyna Ogólna i Nauki o Zdrowiu” 2 (2011), s. 100-104.

9 Por. Ustawa z dnia 1 lipca 2005 r. o pobieraniu, przechowywaniu i przeszczepianiu komórek, tkanek i narządów (ogłoszona 6.09.2005, weszła w życie 1.01.2006), Dz.U. Nr 169, poz. 1411, art. 5.1; Ustawa z dnia 26 października 1995 r. o pobieraniu i przeszczepianiu komórek, tkanek i narządów (obowiązywała do 1.01.2006), Dz.U. Nr. 138, poz. 682, art. 18, 19 i 20. 
państwowe dookreśliły, kto może zostać dawcą oraz w jaki sposób powinno nastąpić przekazanie narządów. Dawstwo zostało tym samym silnie związane z problematyką etyczną. Od samego początku tworzenia się nowej nauki, jaką jest transplantologia, Kościół interesował się nią i określał moralne działania oraz krytykował wszelkie pojawiające się tutaj niedopuszczalne postawy. Życie jest święte i nienaruszalne od poczęcia aż po naturalną śmierć, stąd należy je chronić i reagować na każde nadużycie w tej materii ${ }^{10}$.

\section{Nauka Kościoła o donacji organów}

Kościół zawsze ostrożnie podchodzi do każdego novum, stąd gdy pojawiły się pierwsze próby transplantacji organów, początkowo wypowiedzi papieży na ten temat były bardzo ostrożne, a nawet krytyczne. Warto przywołać tutaj słowa papieża Piusa XI. W encyklice Casti connubi czytamy: „[...] poszczególny człowiek częściami swego ciała tylko do tych celów rozporządza, do których przez przyrodę są przeznaczone. Nie można ich niszczyć lub kaleczyć lub w jaki inny sposób udaremniać naturalnego ich przeznaczenia, chyba że tego wymaga zdrowie ciała całego" ${ }^{11}$. Ciało człowieka jest zatem jego własnością, nie wolno nigdy je okaleczać i choć nie ma tu jeszcze mowy o transplantacji, wyczuwalne zdaje się być negatywne podejście do poświęcania części swojego ciała dla kogoś innego.

Te treści dosadnie zostały omówione przez Piusa XII, którego pontyfikat wypadł na czas pierwszych transplantacji. Podczas Kongresu Histopatologii Systemu Nerwowego w 1952 roku papież powiedział: „człowiek nie jest absolutnym panem swego ciała i swego ducha [...], nie ma więc prawa narażać swej integralności fizycznej i psychicznej w imię medycznych poszukiwań, jeżeli mogą one narażać go na szkodę, poważne ubytki” ${ }^{{ }^{12}}$. Papież stał wówczas na stanowisku mówiącym, że dawstwo organów od organizmu żywego jest niedopuszczalne. W 1953 roku w przemówieniu do lekarzy stwierdzi, że „pacjent, jak każda jednostka, nie ma prawa dysponowania swoim życiem, integralnością swego organizmu i poszczególnymi organami

${ }^{10}$ Por. J. Picewicz, Zagadnienie transplantacji $w$ dokumentach społecznej nauki Kościoła, „Rocznik Filozoficzny Ignatianum” 1 (2015), s. 98-114.

${ }^{11}$ Pius XI, enc. Casti connubi, http://www.opoka.org.pl/biblioteka/W/wP/pius_xi/encykli$\mathrm{ki} /$ casti_connubi_31121930.html (10.01.2016).

${ }_{12}$ Pius xiI, Przemówienie do delegatów, cyt. za J. Picewicz, Zagadnienie transplantacji..., S. 100. 
i ich naturalnymi funkcjami, o ile nie służy to dobru całego organizmu”"13. Papież natomiast pozytywnie odnosił się do pobrania narządów od osób zmarłych. Człowiek utracił już wówczas integralność ciała i ducha, w takim momencie moralne i etyczne jest pobranie od dawcy organów. Pius XII wskazuje, że konieczna jest wcześniejsza zgoda na pobranie organów wyrażona przez rodzinę zmarłego i nie może być mowy o żadnej rekompensacie finansowej za ten czyn.

Następca Piusa XII na Stolicy Piotrowej, Paweł vi, przyjmując transplantologów na specjalnej audiencji, zachęcał ich do dalszych badań i poszukiwań mających na celu dobro pacjenta. Jego postawę odczytano jako przyzwolenie na dalsze próby badań w obrębie wciąż rozwijającej się transplantologii.

Najwięcej jednak wypowiedzi na powyższy temat możemy odnaleźć w nauczaniu Jana Pawła II. Podczas jego pontyfikatu transplantologia osiąga kolejne sukcesy, przeszczepy stają się łatwymi zabiegami, powstaje wiele prac naukowych omawiających ten problem. Podczas kongresów poświęconych przeszczepom papież nazywa osiągnięcia medycyny transplantacyjnej wielkim dobrem. „Technika przeszczepów to wielki krok naprzód w dziejach nauki służącej człowiekowi. Niemało jest dzisiaj ludzi, którzy zawdzięczają życie przeszczepowi organów. W coraz większej mierze technika przeszczepów jawi się jako skuteczna metoda realizacji podstawowego celu wszelkiej medycyny, którym jest służba ludzkiemu życiu”"14.

W encyklice Evangelium vitae papież powraca do tematu transplantacji, przy czym przypomina o wymogach etycznych, którymi należy kierować się podczas donacji organów. Przeszczepy są szansą dla ludzi, którzy utracili nadzieję na normalne życie i funkcjonowanie w społeczeństwie. Jest jednak niezbędne, aby pomoc ta nie budziła żadnych dylematów moralnych ${ }^{15}$. Biskup Rzymu, mówiąc o transplantacji, jako ideał stawia przed oczyma współczesnych ludzi ofiarę z samego siebie złożoną przez Jezusa Chrystusa. Ofiara na krzyżu przez analogię może być porównana z transplantacją i ofiarą złożoną z siebie dla dobra innego człowieka. „Ofiarowanie jakiejś części

${ }^{13}$ Pius XII, Przemówienie do delegatów, cyt. za J. Picewicz, Zagadnienie transplantacji..., S. 100.

${ }^{14}$ Jan Paweł II, Poszukiwania naukowe muszą szanować godność każdej ludzkiej istoty. Przemówienie do uczestników Kongresu Światowego Towarzystwa Transplantologicznego, Rzym, 29.08.2000, 1, http://www.opoka.org.pl/biblioteka/W/wP/jan_pawel_ii/przemowienia/ transplantologia_2908200o.html (12.01.2016).

15 Por. Jan Paweł II, enc. Evangelium vitae [dalej: Ev], 86. 
swojego ciała, złożenie ofiary, która stanie się skuteczna dopiero po śmierci, jest właśnie w wielu przypadkach aktem wielkiej miłości, tej miłości, która daje Życie dla innych. A więc postęp nauk medycznych umożliwił wielu osobom wyniesienie ponad śmierć ich powołania do miłości. Analogicznie do Tajemnicy Paschalnej Chrystusa, śmierć zostaje w pewien sposób zwyciężona, a życie przywrócone. Śmierć i Zmartwychwstanie Pana przedstawiają najwyższy akt miłości, który nadaje głęboką wartość ofiarowaniu swojego narządu przez dawcę dla ratowania innej osoby" ${ }^{16}$.

Kościół akceptuje transplantologię, ale nie jest to akceptacja bezwarunkowa. Katechizm Kościoła Katolickiego mówi: „Przeszczep narządów jest moralnie nie do przyjęcia, jeśli dawca lub osoby uprawnione nie udzieliły na niego wyraźnej zgody. Jest on natomiast zgodny z prawem moralnym i może zasługiwać na uznanie, jeśli zagrożenia i ryzyko fizyczne i psychiczne ponoszone przez dawcę są proporcjonalne do pożądanego dobra u biorcy. Jest rzeczą moralnie niedopuszczalną bezpośrednie powodowanie trwałego kalectwa lub śmierci jednej istoty ludzkiej, nawet gdyby to miało przedłużyć życie innych osób" ${ }^{17}$.

Jan Paweł II w przemówieniu wygłoszonym podczas I Międzynarodowego Kongresu Stowarzyszenia na rzecz Wspólnoty Narządów przestrzegał przed instrumentalnym traktowaniem pacjentów przez lekarzy. Organizm człowieka nie może być traktowany jako zespół narządów, gdyż tworzy on integralną całość, jest ciałem osoby. Stąd niedopuszczalne jest jakiekolwiek sprzedawanie lub wymienianie narządów. Materializm za każdym razem uderza w godność osoby, stąd papież tak mocno przestrzega przed nim, odnosząc się do zagadnienia transplantologii ${ }^{18}$.

Kolejna nadzieja na pozyskiwanie organów do przeszczepu pojawiła się na drodze transplantologii po wprowadzeniu nowej definicji śmierci, czyli śmierci pnia mózgu. Od osób, u których stwierdzono nieodwracalne ustanie wszystkich funkcji mózgu, można bowiem pozyskać organy w lepszej formie niż od dawców martwych. Dylematy pojawiające się przy zastosowaniu kryteriów harwardzkich wymagały kolejnych orzeczeń płynących

${ }^{16}$ Jan Paweł II, Podarować cząstkę siebie. Fragmenty przemówienia wygłoszonego do uczestników Kongresu Transplantologicznego, Watykan, 20.06.1996, „W Drodze” 1 (1997), s. 67.

${ }^{17}$ Katechizm Kościoła Katolickiego, Poznań 2002, 2296.

18 Por. Jan Paweł II, Przemówienie na I Międzynarodowym Kongresie, w: W trosce o życie, red. K. Szczygieł, Tarnów 1998, s. 220. 
ze strony Stolicy Apostolskiej. W 2000 roku Jan Paweł in podczas Kongresu Światowego Towarzystwa Transplantologicznego w Rzymie pozytywnie zaopiniował przyjęte nowe kryteria śmierci. „W tym miejscu można orzec, że przyjęte w ostatnim okresie kryterium, na podstawie którego stwierdza się śmierć, a mianowicie całkowite i nieodwracalne ustanie wszelkiej aktywności mózgowej, jeśli jest rygorystycznie stosowane, nie wydaje się pozostawać w sprzeczności z istotnymi założeniami rzetelnej antropologii”"19. Późniejsze jednak naukowe dyskusje o niepoprawności zastosowania nowych kryteriów śmierci skłoniły Stolicę Apostolską do dalszej debaty. Pomimo to, na obecnym poziomie wiedzy medycznej moralnie godziwe jest pobranie narządów od osób, u których orzeczono śmierć mózgową, a które wyraziły zgodę na pobranie narządów.

Papież podaje zatem konkretne wskazania, kiedy można dopuścić do donacji organów. Przestrzega przed instrumentalnym traktowaniem człowieka. Wykazuje, jakie nadużycia mogą pojawić się przy pobieraniu narządów. Jego wskazania stały się wytycznymi na kolejne lata rozwijającej się transplantologii.

\section{Obowiązek donacji organów}

Wobec tak przedstawionego problemu i poparcia przez nauczanie Kościoła rozwoju transplantologii można postawić pytanie, czy człowiek wierzący jest zobowiązany do donacji organów.

Powyższa kwestia została także omówiona przez teologię moralną. Już w swoim nauczaniu Jan Paweł II stwierdził, że podstawą do pobrania organów jest zawsze zgoda dawcy. W prawodawstwie polskim i w wielu krajach świata nadal funkcjonuje pojęcie zgody domniemanej zakładające, że jeśli pacjent nie wyrazi sprzeciwu na pobranie organów, lekarze po jego śmierci mają prawo to uczynić. Zgoda domniemana jest zatem sprzeczna $\mathrm{z}$ nauką Kościoła katolickiego, który wskazuje, że zgodę na pobranie narządów musi wyrazić dawca lub bynajmniej opiekun prawny ${ }^{20}$. Papież wskazuje, że wszelkie naukowe poszukiwania muszą szanować godność osobistą, jaką posiada

19 Jan Paweł II, Poszukiwania naukowe musza szanować godność każdej ludzkiej istoty..., 5; zob. T. Biesaga, Kontrowersje wokół nowej definicji śmierci, http://biesaga.info/wpcontent/uploads/2009/11/IV.-1.-Biesaga-T.-Kontrowersje-wokół-nowej-definicji-śmierci-MP-22006-20-23+28.pdf (3.01.2016).

${ }^{20}$ Por. J. Picewicz, Zagadnienie transplantacji w dokumentach społecznej nauki Kościoła..., s. 9. 
każdy człowiek, a zatem jeśli ma być on dawcą, musi najpierw świadomie wyrazić na to zgodę ${ }^{21}$.

Zgoda domniemana stoi często w sprzeczności ze zgodą oświadczoną i wyrażoną przez człowieka lub jego bliskich. najczęstszym problemem jest to, że niewielu nadal ludzi deklaruje chęć bycia dawcą, zwłaszcza gdy jego życie przebiega normalnym tokiem i nic nie wskazuje na to, by miało być wcześniej przerwane. Dylematy powstają w momencie osobistych tragedii, kiedy za dawców musi decydować rodzina, często nieprzygotowana na taki akt zgody. Stąd warto rozważyć problem donacji za życia danej osoby.

Człowiek w punktu widzenia etyki i teologii moralnej nie ma obowiązku oddawać swoich organów innym. Każdy akt oddania swojego narządu innej chorej osobie - przy wykluczeniu jakiejkolwiek korzyści - należy nazwać aktem heroicznym ${ }^{22}$.

W takiej sytuacji, aby pozyskać jak największą liczbę organów do przeszczepów, należy rozwijać pośród ludzi tzw. logikę daru. Człowiek jest istotą społeczną i niejednokrotnie poświęca jakieś własne dobro dla innych ludzi, zwłaszcza gdy chodzi o bliskich z rodziny. Darowanie części swojego ciała jest poświęceniem dobra posiadanego na rzecz innych. Oczywiście, należy tu pominąć takie rozumienie poświęcenia siebie, w którym człowiek ponosiłby jakiś wielki uszczerbek na własnym zdrowiu. Działanie dawcy nie może unicestwiać ani godzić w dobro mojego istnienia. Dar jest to ofiarowanie komuś własnego, ważnego dobra, przy czym jest ono udziałem szczęścia obojga ludzi. Darowanie swojego organu jest darowaniem samego siebie. Nie jest to uprzedmiotowienie dawcy, ponieważ nie mamy tutaj do czynienia ze sprzedażą lub kupnem ${ }^{23}$.

Tą myśl logiki daru w kontekście transplantacji szczególnie rozwiną Gilbert Meileander ${ }^{24}$, który stwierdza: „język daru czy darowania jest jedynym

${ }^{21}$ Zob. Jan Paweł II, Poszukiwania naukowe musza szanować godność każdej ludzkiej istoty..., 3: „Bezpośrednią konsekwencją [...] mającą wielkie znaczenie etyczne, jest konieczność wyrażenia przez dawcę świadomego przyzwolenia. Ludzki «autentyzm» tak doniosłego aktu wymaga, aby jednostka została należycie poinformowana o procesach, jakie się z nim wiążą, by mogła swobodnie i świadomie wyrazić swe przyzwolenie lub odmowę".

${ }^{22}$ Por. M. Machinek, Śmierć $w$ dyspozycji człowieka: teologia moralna wobec problemów etycznych u kresu życia ludzkiego, Olsztyn 2001, s. 43.

${ }^{23}$ Por. G. Hołub, O dwu sposobach pozyskiwania organów do transplantacji, „Studia Gdańskie" 25 (2009), s. 142.

${ }^{24}$ Gilbert Meileander, bioetyk, redaktor czasopisma „New Atlantis”, pracownik Centrum Etyki i Kultury w Notre Dame, członek Rady Prezydenckiej ds. Bioetyki w UsA (2002-2009), autor wielu publikacji moralno- etycznych z zakresu bioetyki. 
posiadanym przez nas sposobem na to, aby kontynuować proces transplantacji, a zarazem uszanować to, że jesteśmy istotami cielesno-duchowymi. Język ten pozwala nam również na żywienie przekonania, że transplantowany organ niesie ze sobą stałe przywiązanie do tego, kto jest dawcą, ponieważ daje on nie tyle organ, ale samego siebie" 25 .

Logiki daru człowiek szczególnie uczy się w rodzinie. Tutaj czymś niezbędnym staje się poświęcenie, złożenie daru z siebie dla dobra drugiego człowieka. Darowanie z siebie staje się wolnym aktem podmiotu. Do tak pojętego daru z siebie potrzeba ciągle dojrzewać i wzrastać. Stąd bardzo często w przypadku niezbędnych transplantacji do głosu dochodzi najbliższa rodzina. Człowiek wychowywany w miłości jest w stanie dokładnie zrozumieć, czym jest dar ofiarowany z siebie i w przypadku konieczności przeszczepu świadomie godzi się na przekazanie części siebie potrzebującemu ${ }^{26}$.

Logika daru może być rozpowszechniana również poza rodziną. Działające dziś na szeroką skalę organizacje charytatywne oraz docierające do wszystkich media są niezastąpionym środkiem krzewienia w społecznościach odpowiednich postaw.

Logika daru nie może być jednak nigdy objęta jakąkolwiek formą powinności moralnej. Tak więc jeśli człowiek nie dojrzeje do odpowiedniego rozumienia tej ofiary z siebie, nie zaciąga tym samym żadnej moralnej winy. Przekazanie swojego narządu w formie daru dla potrzebującej osoby nie będzie zatem obowiązkiem, ale aktem życzliwości, międzyludzkiej solidarności i przejawem realizacji pewnych ideałów, które każdy człowiek posiada w sobie, a które realizuje poprzez przywołaną logikę daru.

Dawcą może być zarówno człowiek, który żyje i przekazuje swoje organy świadomie, mając szczytny cel ratowania innych, jak i ten, który uznany i określany jest jako dawca zmarły. W drugim przypadku, z moralnego punktu widzenia, niezbędna jest jednak jego świadoma zgoda, wyrażona za życia, na pobranie organów po śmierci.

${ }^{25}$ G. Meilaender, Gifts of the body, „The New Atlantis” $2006 \mathrm{nr}$ 13, s. 25-35.

${ }^{26}$ Por. K. Krajewski, Etyka rodzinna, w: U źródeł tożsamości kultury europejskiej, red. T. Rakowski, Lublin 1998, s. 182-187. 


\section{Nadużycia pojawiające się przy transplantologii}

W swoim nauczaniu Jan Paweł II zwrócił uwagę, że osoba może przekazać innym tylko takie narządy, tylko taką swoją część, która nie narazi ją samą na jakieś choroby lub utratę własnego zdrowia lub życia. Poprzez donację człowiek nie może utracić także swojej tożsamości osobowej. Organy niezbędne do życia mogą być pobrane tylko po śmierci człowieka ${ }^{27}$. Papież przestrzega przed możliwym błędem, jakim jest pobranie narządów przed pewnym rozpoznaniem śmierci pacjenta. Narządy pojedyncze można pobrać od człowieka tylko wówczas, gdy obiektywne kryteria śmierci pozwalają stwierdzić zgon ${ }^{28}$.

Człowieka nie należy traktować nigdy jako środka do celu, ale jako cel sam w sobie ${ }^{29}$. Wynika to z posiadanej przez każdego godności. Pomiędzy człowiekiem a rzeczą istnieje ta różnica, że rzeczy mają swoją cenę, osoba ludzka zaś jest poza wszelką ceną. Moralność chrześcijańska stoi na straży tej godności, aby nigdy nie doszło do tego, co proponowali w ubiegłych epokach Karol Marks, Georg W. F. Hegel czy Thomas Hobbes, a mianowicie zrównanie wartości osoby ludzkiej z rzeczami.

Jeśli życie człowieka posiada wartość najwyższą, to w kontekście transplantologii należy sprzeciwić się różnego rodzaju nadużyciom, jakie wciąż się tu pojawiają. Jak można zauważyć, nadal jest więcej ludzi chorych niż organów posiadanych do przeszczepu. Powstała więc myśl o udzieleniu rekompensaty finansowej człowiekowi, który odda swój organ potrzebującym. W świetle przywołanej myśli narodził się tzw. handel organami, przed którym przestrzegał w swoich wypowiedziach Jan Paweł II. I choć niemal wszystkie kraje świata postrzegają taki akt jako zło i pociągają zań do odpowiedzialności karnej, to czarny rynek handlu organami bardzo się rozwinął. Co jakiś czas media informują o porwaniu dzieci, ale i starszych ludzi w celu pobrania od nich narządów.

Handel narządami, tkankami i komórkami jest zazwyczaj spowodowany przez niskie standardy socjalno-ekonomiczne. Ludzie z biednych państw

${ }^{27}$ Por. Jan Paweł II, Przemówienie na I Międzynarodowym Kongresie..., s. 220.

${ }^{28}$ Por. Jan Paweł II, Przemówienie do uczestników Kongresu Światowego Towarzystwa Transplantologicznego, zob. http://www.oswiadczeniewoli.com.pl/lekarz/papiez.pdf(12.01.2016); EV 15.

${ }^{29}$ Kantowska zasada mówi: „Postępuj tak, byś człowieczeństwa tak w twej osobie jako też w osobie każdego innego używał zarazem jako celu, nigdy tylko jako środka” (I. Kant, Uzasadnienie metafizyki moralności, tłum. R. Ingarden, Warszawa 1984, s. 64). 
świata, takich jak Pakistan, Kolumbia, Filipiny, Egipt, czy nawet z Europy: Turcji, Mołdawii i Rumunii, postanawiają poprzez oddanie narządu (najczęściej nerki bądź fragmentu wątroby) poprawić swój byt ${ }^{30}$. Silke Meyer mówi: „[...] handel organami wiąże się z uzyskaniem środków na życie, w wypadku ludzi, którzy żyją na bardzo niskim poziomie społeczno-ekonomicznym. Ludzie ci są skłonni sprzedać organ - zwykle nerkę, ponieważ jest to organ najczęściej pobierany od żyjących dawców - w celu polepszenia swoich warunków życia" ${ }^{31}$.

Od dłuższego czasu istnieją ludzie trudniący się wyszukiwaniem i przeprowadzaniem nielegalnych transakcji. Są to tzw. "porywacze organów” (organ snatchers), którzy wyszukują np. młodych zdrowych mężczyzn z biednych krajów, oferują im łatwy zarobek, przy czym sami zabierają większą część pieniędzy. Sumy oferowane za nerkę kilkukrotnie przekraczają cenę, którą zaoferowano dawcy. Jak donoszą organizacje zwalczające czarny handel, dawca otrzymuje tysiąc dolarów, podczas gdy nerka sprzedawana jest za cenę od 5 do 15 tys. dolarów ${ }^{32}$.

Innym nadużyciem, z jakim można spotkać się w dziedzinie transplantologii, jest problem pobierania tkanek i narządów $\mathrm{z}$ embrionów i dzieci anencefalicznych. Pierwszy taki przypadek opisano w 1987 roku w UsA. Na Loma Linda University Medical Center w Południowej Kalifornii pobrano serce od dziecka, u którego stwierdzono niepoprawnie rozwinięty mózg ${ }^{33}$. Kilka lat później w 1992 roku rozgorzała dyskusja wokół sprawy Baby Theresa, dziecka anencefalicznego, którego rodzice urodzili tylko po to, aby przekazać jego narządy do przeszczepu. Rodzice wiedzieli, że dziecko jest chore, ma niedorozwój mózgu i że umrze chwilę po urodzeniu. Ich intencją było podtrzymanie płodu dla celu transplantacji ${ }^{34}$. Działająca przy American Medical Association Rada ds. Etyczno-Prawnych w 1994 roku w swoim orzeczeniu dopuściła możliwość pobrania narządów od takich noworodków jeszcze za ich życia. Uzasadniono tę decyzję twierdze-

${ }^{30}$ Por. R. Panjabi, The sum of a human's parts: global organ trafficking in the twenty-first century, „Pace Environmental Law Review” 28 (2010) No. 1, s. 75.

${ }^{31}$ S. Meyer, Trafficking in human organs in Europe. A myth or an actual threat?, „European Journal of Crime" 14 (2006), s. 215.

${ }^{32}$ Por. G. Hołub, O dwu sposobach pozyskiwania organów do transplantacji..., s. 131-132.

${ }_{33}$ Por. http://www.mp.pl/etyka/kres_zycia/show.html?id=58520 (17.01.2016).

${ }^{34}$ Por. A. Kimbrell, The human body shop: the engineering and marketing of life, San Francisco 1994, s. 58. 
niem, że dziecko anencefaliczne nie jest ani potencjalną, ani żywą osobą. Za czynnik stanowiący o istnieniu osoby uznano świadomość. Płodom z niewykształconym mózgiem, niemającym świadomości odmówiono praw przysługującym innym dzieciom, zezwolono natomiast na pobranie od nich narządów ${ }^{35}$.

Sprawa transplantacji wymagała zatem nie tylko moralnego usankcjonowania, czego w swoim nauczaniu dokonał Jan Paweł II, ale przede wszystkim uregulowania prawnego poprzez ustawy. Ich celem jest wyeliminowanie wszelkich nadużyć związanych z przeszczepianiem narządów. Takie ustawy pojawiają się na całym świecie wprost proporcjonalnie do narastających problemó ${ }^{36}$. W Polsce sprawę transplantacji reguluje Ustawa $\mathrm{z}$ dnia 1 lipca 2005 roku o pobieraniu, przechowywaniu i przeszczepianiu komórek, tkanek i narządów. Art. 3 ustawy zabrania pobierania i przyjmowania zapłaty lub innej korzyści majątkowej od biorcy narządu. Prawodawca przywiduje karę dla każdego, kto nabywa lub sprzedaje organy lub komórki, a także dla tego, kto rozpowszechnia informacje na podany temat ${ }^{37}$. Pojawiające się wciąż nowe ustawy mają na celu zapobiec różnego rodzaju nadużyciom. Istotna jest ciągła współpraca różnych środowisk, które będą nieustannie piętnować każdy nieetyczny zabieg transplantacyjny, a z drugiej strony promować świadome opowiadanie się za wyrażaniem przez jak największą liczbę ludzi zgody na dawstwo organów w przypadku śmierci. Świadoma zgoda nie jest tym samym, co zgoda domniemana, toteż warto podejmować różne zabiegi, aby pozyskiwać jak najwięcej odpowiedzialnych dawców. Można to uczynić poprzez promowanie pozytywnych postaw ludzi, którzy rozumieją, jak ważna jest pomoc potrzebującym chorym ludziom oraz jak istotna jest logika daru we współczesnym świecie. Dzięki jasnym i jedno-

${ }^{35}$ Por. K. G. Gervais, Redefining death, New Haven 1986, s. 138; zob. http://www.mp.pl/etyka/kres_zycia/show.html?id=58520 (17.01.2016).

${ }^{36}$ Ustawy zakazujące handlu organami znajdują się np. w dokumentach onz, zob. Rezolucja legislacyjna Parlamentu Europejskiego z dnia 22 kwietnia 2008 r. w sprawie dawstwa i przeszczepiania narządów: działania polityczne na poziomie UE. (2007/2210(INI)); P. Degani, Prawa człowieka a handel kobietami i młodymi ludźmi w Europie. Przybornik edukacyjny, tłum. B. Grodzka, A. Polak, Padwa 2007, s. 7.

${ }^{37}$ Por. Ustawa z dnia 1 lipca 2005 roku o pobieraniu, przechowywaniu i przeszczepianiu komórek, tkanek i narządów, art. 3, 43, 44; zob. S. Buczyński, P. Snopek, Aspekty kryminologiczne nielegalnego obrotu narządami, tkankami oraz komórkami ludzkimi, „Hygeia Public Health” 49 (2013), s. 229-234. 
znacznym deklaracjom uniknie się problematycznego etycznie dylematu powstającego przy zgodzie domniemanej ${ }^{38}$.

\section{Zakończenie}

Podsumowując, należy stwierdzić, że zmiany w podejściu do problemu transplantacji widoczne w nauczaniu Magisterium Kościoła i w mentalności całych społeczeństw, pozwoliły ukazywać ją dzisiaj w innym świetle. Etyczne poparcie transplantologii umożliwiło dalszy jej rozwój. Moralność chrześcijańska wpłynęła na pogłębienie zagadnienia donacji organów o wątki teologiczne, ukazując akt przekazania swoich organów jako najgłębszy aspekt człowieczeństwa polegający na złożeniu daru z siebie dla drugiego człowieka. Logika daru, odpowiednio pojęta i wyjaśniana, jest drogą ku pozyskaniu jeszcze większej liczby organów dla ratowania innych ludzi, z pominięciem kontrowersyjnej zgody domniemanej. Magisterium Kościoła szeroko opisuje godność, jaką ma człowiek, i prawa, jakie z niej wynikają, stąd sprzeciwia się wszelkim nadużyciom, które mogą pojawiać się w tej dziedzinie.

Tylko dzięki odpowiedniemu rozwojowi człowieka, wychowaniu go w rodzinnej atmosferze promującej najwyższe wartości, kształtowaniu właściwie pojętej logiki daru z siebie można osiągnąć cel, którym jest poszanowanie życia innego człowieka i społeczna za nie odpowiedzialność. Realizując wspomniane działania, pozyskamy więcej dawców organów, unikniemy problemów związanych ze zgodą domniemaną oraz wszelkich nieetycznych postępowań obecnych dzisiaj przy donacji organów.

\section{Bibliografia}

Biesaga T., Kontrowersje wokół nowej definicji śmierci, „Medycyna Praktyczna” 2 (2006), s. 20-28.

Buczyński S., Snopek P., Aspekty kryminologiczne nielegalnego obrotu narzadami, tkankami oraz komórkami ludzkimi, „Hygeia Public Health” 49 (2013), s. 229-234. Gardocka M., Problem zgody domniemanej w polskiej transplantologii, „Warszawskie Studia Teologiczne" 26 (2013) nr 1, s. 247-26o.

${ }^{38}$ Por. M. Gardocka, Problem zgody domniemanej w polskiej transplantologii, „Warszawskie Studia Teologiczne" 26 (2013) nr 1, s. 247-26o. 
Gervais K. G., Redefining death, New Haven 1986, http://www.mp.pl/etyka/kres_zy$\mathrm{cia} /$ show.html?id=58520 (17.01.2016).

Hoffenberg R., Christiaan Barnard: his first transplants and their impact on concepts of death, „British Medical Journal” 12 (2001), s. 22-27.

Hołub G., $O d w u$ sposobach pozyskiwania organów do transplantacji, „Studia Gdańskie" 25 (2009), s. 129-146.

Jan Paweł II, Encyklika Evangelium vitae.

Jan Paweł iI, Podarować cząstkę siebie. Fragmenty przemówienia wygłoszonego do uczestników Kongresu Transplantologicznego, Watykan, 20.06.1996, „W Drodze" 1 (1997), s. 67.

Jan Paweł II, Poszukiwania naukowe muszą szanować godność każdej ludzkiej istoty. Przemówienie do uczestników Kongresu Światowego Towarzystwa Transplantologicznego, Rzym, 29.08.200o, http://www.opoka.org.pl/biblioteka/W/wP/ jan_pawel_ii/przemowienia/transplantologia_2908200o.html (12.01.2016).

Jan Paweł II, Przemówienie na I Międzynarodowym Kongresie Światowego Towarzystwa Transplantologicznego, w: W trosce o życie, red. K. Szczygieł, Tarnów 1998. Kant I., Uzasadnienie metafizyki moralności, tłum. R. Ingarden, Warszawa 1984. Katechizm Kościoła Katolickiego, Poznań 2002.

Kimbrell A., The human body shop: the engineering and marketing of life, San Francisco, Harper 1994.

Krajewski K., Etyka rodzinna, w: U źródeł tożsamości kultury europejskiej, red. T. Rakowski, Lublin 1998, s. 182-187.

Lanzetta M., Petruzzo P., Vitale G. i in., Human hand transplantation: what have we learned?, „Transplantation Proceedings” 36 (2004), s. 664-668.

Machinek M., Śmierć $w$ dyspozycji człowieka: teologia moralna wobec problemów etycznych u kresu życia ludzkiego, Olsztyn 2001.

Meilaender G., Gifts of the body, „The New Atlantis” Summer 2006 nr 13, s. 25-35. Meyer S., Trafficking in human organs in Europe. A myth or an actual threat?, „European Journal of Crime” 14 (2006), s. 208-229.

Panjabi R., The sum of a human's parts: global organ trafficking in the twenty-first century, „Pace Environmental Law Review” 28 (2010) No. 1, s. 1-145.

Picewicz J., Zagadnienie transplantacji w dokumentach społecznej nauki Kościoła, „Rocznik Filozoficzny Ignatianum” 1 (2015), s. 98-114.

Pius XI, Encyklika Casti connubi, http://www.opoka.org.pl/biblioteka/W/wP/ pius_xi/encykliki/casti_connubi_31121930.html (10.01.2016).

„Poltransplant. Biuletyn Informacyjny” maj 2014, http://www.poltransplant.org.pl/ statystyka_2015.html (12.01.2016). 
Skalski J., Historia przeszczepiania narządów, „CX-News” 28 (2009) nr 2, s. 243-254. Sobiak J., Przeszczepianie narządów i komórek krwiotwórczych - rys historyczny, „Nowiny Lekarskie” 80 (2011) nr 2, s. 157-161.

Ustawa z dnia 26 października 1995 r. o pobieraniu i przeszczepianiu komórek, tkanek i narządów (obowiązywała do dn. 1 stycznia 2006 r.), Dz.U. Nr. 138, poz. 682. Ustawa $\mathrm{z}$ dnia 1 lipca 2005 r. o pobieraniu, przechowywaniu i przeszczepianiu komórek, tkanek i narządów (ogłoszona dn. 6 września 2005 r., weszła w życie dn. 1 stycznia 2006 r.), Dz.U. Nr 169, poz. 1411.

W trosce o życie, red. K. Szczygieł, Tarnów 1998.

Wałaszewski J., Stryjecka-Rowińska D., Dawcy narządów, rozpoznanie śmierci mózgowej, w: Transplantologia kliniczna, red. W. Rowiński, J. Wałaszewski, L. Pączek, Warszawa 2004, s. 35-49.

\section{Streszczenie}

Transplantologia jest dzisiaj bardzo ważnym działem całej medycyny. Dzięki jej zabiegom coraz więcej ludzi chorych dostaje szanse na dalsze normalne życie. Problemem jest jednak większa liczba oczekujących na przeszczep niż liczba chętnych dawców. Aby wzrastała liczba transplantacji, niezbędne jest odpowiednie wychowywanie ku temu społeczeństwa. Jednym ze sposobów jest rozwijanie postawy, którą można opisać terminem „logika daru”. Człowiek jako istota społeczna jest w stanie poświęcić dla innych ludzi bardzo wiele, nawet ofiarować samego siebie. Postawę osoby, która decyduje się oddać swoje narządy, należy określić jako altruistyczną. Do takiej cnoty trzeba jednak człowieka odpowiednio wychować. Jest to tym samym droga do pozyskania większej liczby organów i wykluczenia niemoralnych nadużyć, takich jak chociażby handel narządami.

Artykuł omawia problem transplantacji. Przedstawia, jak zmieniało się stanowisko Kościoła katolickiego wobec donacji organów, ukazuje nadużycia, które i dzisiaj są towarzyszą transplantacjom. Promuje „logikę daru”, czyli postawę przeciwną egoistycznemu postrzeganiu swojego ciała jako własności bezwzględnej.

\section{Słowa kluczowe}

transplantologia, donacja organów, pozyskiwanie organów, logika daru, handel organami 


\section{Summary}

\section{Donation of organs and the logic of the gift.}

\section{Christian look at the problem transplant}

Transplantation today is a very important section of the entire medicine. With its prosidures more and more sick people get a chance to continue rather a normal life. The problem however, is more waiting patients for a transplant than the number of available donors. To increase the number of transplantation procedures is necessary for upbringing of a proper society. One way is to develop an attitude that could be described by the term "logic of gift." The man as a social being, is willing to sacrifice for other people very much, even the sacrifice of himself. The attitude of the person who decides to give his organs is to be described as altruistic. For such virtues, however, you need to properly educate the people. This is the way to obtain more body organs and to prevent immoral abuses such as organ trafficking. The article discusses the problem of transplantation. It shows how the developement of the Catholic Church thought about donating organs, reveals abuses which today are present at transplantation. Promotes the "logic of gift" or attitude opposite egoistic perception of your body as an absolute property.

\section{Keywords}

transplantation, organ donation, organ acquisition, the logic of the gift, organ trafficking 